Assist. Prof. Dr. Büșra BAKioĞLU' Karamanoglu Mehmetbey University Karaman / Turkey
Original scientific paper

UDC: 37.013 .76

DOI: $10.5937 /$ IstrPed2102483B

\title{
TEACHER CANDIDATES' TEACHING-LEARNING CONCEPTIONS AND SELF-EFFICACY IN ORGANIZING OUT-OF-SCHOOL TRIPS: THE MEDIATING ROLE OF LIFELONG LEARNING
}

\begin{abstract}
This study aimed to examine whether lifelong learning has a mediating role in the relationship between teacher candidates' teaching-learning conceptions and self-efficacy in organizing out-of-school trips. Structural Equation Modeling was used to determine this relationship. The study sample consisted of 341 teacher candidates. The study data were collected using the Teaching and Learning Conceptions Questionnaire, the Self-Efficacy Belief Scale for Planning and Organizing Educational Out-of-school Trips, and the Lifelong Learning Scale. Participants' ages ranged from 18 to $30(M=23.26$; $S D=2.62)$. According to the findings of the study, positive and significant relationships were found between teacher candidates' teaching-learning conceptions and lifelong learning and their self-efficacy in organizing out-of-school trips. The structural equation model of the study was confirmed. In conclusion, teacher candidates' lifelong learning tendencies were found to strengthen the relationship between teaching-learning conceptions and self-efficacy in organizing out-of-school trips.
\end{abstract}

Keywords: Teacher candidate, teaching and learning conceptions, self-efficacy in organizing out-of-school trips, lifelong learning.

\section{Introduction}

The changing world has brought about some differences also in teaching-learning conception. There has been a shift from teacher-centered teaching towards student-centered teaching conceptions, where reward and punishment are not emphasized. This has made the constructivist approach, which emerged especially in developed countries after the 1980s, popular. Vygotsky, one of the scientists who laid the foundations of constructivism, brought a socio-cultural perspective on learning. According to him, for learning and development to occur, individuals must interact with the social environment (Kozulin, 2003). Out-of-school learning environments are one of the environments where the individual interacts best with the social environment and can structure knowledge. Out-of-school learning environments are nonformal learning environments that cover a lifelong process (Oner \& Ozturk, 2019) where learners play an active role in structuring and developing knowledge, as supported by a constructivist conception. The UNESCO commission on the development of education, which convened in 1972, made four proposals. The first of these included the statement, "it is wrong to limit education to age and buildings." Therefore, out-of-school learning environments have gained importance in lifelong learning (Roulstone, 2010; Soran, Akkoyunlu, \& Kavak, 2006). Lifelong learning is a general arrangement covering all kinds of formal and non-formal

\footnotetext{
${ }^{1}$ busrabakioglu@kmu.edu.tr
} 
educational activities, aiming to restructure the existing education system and to improve education other than formal education (Gulec, Celik \& Demirhan, 2012). Teachers are the individuals who will make this arrangement. When teachers have lifelong learning competencies, this means that they can achieve social change effectively (Yildirim, 2015). Fenwick (2001) mentions two important and prominent trends in teacher education. The first includes expanding the professional development process of teacher candidates with the concept of lifelong learning, and the other aims to make individual teaching abilities comprehensive with practices performed in society. In this context, Chapman et al. (2003) emphasize the necessity of developing teacher candidates' competencies for applying the lifelong learning and constructivist approach in education to become a lifelong learning society. Saisana and Cartwright (2007) expressed the building blocks of lifelong learning in four sections: learning to know, learning to do, learning to live together, and learning to exist. These building blocks are about learning to know and learning to do. One of the roles of higher education institutions in lifelong learning is to provide professional development opportunities (Dinevski \& Dinevski, 2004; Kivrak, 2007). It is thought that having self-efficacy in teaching in out-of-school learning environments is related to professional development. Moreover, in the Faure report published by UNESCO in 1972, lifelong learning was described as in the following statement: "Teaching should adapt to self-learning, contrary to the understanding of traditional education." For this reason, it is thought that the learning-teaching understanding of the individual is related to lifelong learning. Therefore, this study aims to examine whether lifelong learning has a mediating role in the relationship between teacher candidates' teaching-learning conceptions and self-efficacy trips out of school.

\subsection{Teaching-Learning Conceptions}

Teaching-learning conceptions involve individuals' conceptions of what constitutes effective teaching-learning and how these affect students' learning processes (Brownlee, Purdie \& Boulton-Lewis, 2001). Teaching-learning conceptions are discussed under two headings: traditional-teacher-centered and constructivist-student-centered (Aypay 2011; Brooks \& Brooks, 1999; Chan \& Elliott, 2004; Teo, Chai, Hung, \& Lee, 2008). In the traditional conception, a teacher-centered approach dominates, students are passive, extrinsic motivation is needed, memorization is the primary practice of learning, and knowledge is taken from the outside world as a whole independent of the learner (Bas \& Beyhan, 2013; Ozden, 2014; Skinner, 1953; Yurdakul, 2015). In the constructivist approach, on the other hand, a student-centered approach is dominant, students are active, collaborative learning is actively applied, and learners make sense of their knowledge and experience and actively participate in the construction and development of knowledge (Cheng, Chan, Tang, \& Cheng, 2009). The teaching-learning conceptions of teachers play an effective role in their educational behaviors, practices, and strategies to be used (Abdelraheem 2004; Aydin, 2010; Richardson, 1996). In other words, teachers' beliefs and conceptions have an important effect on the success of the implementation of educational reforms (Aydin, 2010; Karhan, 2007; Khader, 2012; Stipek, Givvin, Salmon, \& Macgyvers, 2001). Accordingly, it is thought that it is important to know the teachinglearning conceptions of teacher candidates and to reveal whether they are correlated with some variables. There are some studies in the literature revealing the relationship between teaching-learning conceptions and self-efficacy (Yener \&Yllmaz, 2017; Sacici, 2013). These studies have found a positive and significant relationship between perceived self-efficacy and teaching-learning conceptions. Bas (2014) argued that teachers' teaching-learning conceptions differed significantly by gender, professional seniority, and educational status. In addition, epistemological beliefs were also found effective in predicting teaching-learning conceptions (Akyildiz, 2014; Aypay, 2011; Bikmaz, 2017; Karhan, 2007). These findings in the literature showed 
that variables affecting the teaching-learning conception were general self-efficacy, individual innovativeness, seniority and gender, and epistemological beliefs.

\subsection{Self-Efficacy in Organizing Out-of-SchoolTrips}

Today, teaching and learning are carried out not only within the school walls but also out of school in a planned manner. Out-of-school learning environments include both "real out-ofschool learning environments", such as museums, science centers, industrial institutions and organizations, zoos, planetariums, or nature camps and "digital/virtual out-of-school learning environments", such as social media, web with educational content, web 2.0 tools, etc (Karademir, 2018). Teachers who want to conduct lessons in out-of-school environments should know well what they should do in such environments so that they can fulfill their goals effectively and efficiently. Things to consider in out of school learning environments are divided into three: before-, during- and after-trip preparations (Bozdogan, 2007; DeWitt \& Osborne, 2007). The before-trip stage includes educational preparations, bureaucratic procedures (e.g. permits), transportation, food and beverage, and accommodation possibilities. The during-trip activities include the implementation of the plan prepared before the trip. The after-trip stage consists of activities for reinforcing what has been learned after returning to school. It is known that the knowledge acquired in out-of-school learning environments is retained for a long time (Anderson, Kisiel, \& Storksdieck, 2006), these environments allow students to learn in depth, and that activities carried out in these environments provide cognitive and social benefits to students (Rapp, 2005). Besides, most teachers think that extracurricular activities have a positive effect on students (Cox-Petersen, Marsh, Kisiel, \& Melber, 2003; Griffin, 2004; Lucas, 2000). Despite all these positive effects, some studies have revealed that teachers do not have enough knowledge and self-efficacy regarding the lessons conducted in out-of-school settings, they, therefore, feel anxious, and that they are incompetent to guide students in these environments (Bozdogan, 2012; Griffin \& Symington, 1997; Kisiel, 2005; Orion \& Hofstein, 1994; Thomas, 2010). For this reason, it is important to examine teacher candidates' self-efficacy beliefs about out-of-school environments. Self-efficacy belief shows whether a person can exhibit necessary behaviors to achieve a desired outcome (Bandura, 1977). Self-efficacy has been discussed in Bandura's Social Cognitive Learning Theory. Bandura argued that an individual's self-efficacy belief is influenced by many areas, such as personal experiences, indirect experiences, verbal persuasion, and psychological and physiological state. The concept of self-efficacy, which is considered important in many professions, is also very significant in the teaching profession. Teacher self-efficacy is the belief of teachers that they have the capacity to affect students' performance or exhibit the behaviors necessary to successfully fulfill their duties (Aston, 1984). It is also related to the teacher's behaviors, being open to new ideas, and developing a positive attitude for teaching (Tschannen \& Woolfolk, 2001). Teachers with high self-efficacy beliefs use different teaching methods in their teaching practices, search ways for improving the teaching methods they use, and do student-centered lessons (constructivist conception), whereas teachers with low self-efficacy do teacher-centered lessons (traditional conception) (Henson, 2001; Plourde,2001). In studies revealing the relationship between teaching-learning conceptions and self-efficacy, a significant positive relationship has been found between perceived self-efficacy and teaching-learning conceptions (Yener \& Yilmaz, 2017; Sacici, 2013). Also, a positive relationship has been found between lifelong learning and self-efficacy (Garipagaoglu, 2013), academic self-efficacy (Kozikoglu \& Onur, 2019), and teacher self-efficacy (Akyol, 2016; Ayra \& Kosterelioglu, 2015). 


\subsection{Lifelong Learning}

According to Delors (1996), lifelong learning is a long-term learning process, where individualsare aware of the available possibilities and utilize them appropriately, can find solutions to the problems they encounter with their problem-solving skills, and live peacefully in society. Lifelong learning is based on the idea of an educational approach beyond traditional teaching (Bagci, 2007). According to Holmes (2002), in an education program shaped according to lifelong learning, all materials, methods, and techniques of learning and teaching are different from those of the traditional teaching approach. Teachers, who have an important role in teaching-learning approaches, should get rid of traditional approaches and adapt to the changes that come with lifelong learning (State Planning Organization [SPO], 2001). With the Prague Ministerial Meeting (2001), the place of lifelong learning in higher education has started to gain importance. In this meeting, having the students gain the concept of lifelong learning in higher education was discussed, and the necessity of using learning strategies to become a qualified individual in the information age was emphasized. This is because the development of appropriate learning methods related to the rapidly changing knowledge and skill needs of individuals during and after higher education is related to lifelong learning competencies (Demirel \&Yagci, 2012). In the report published by UNESCO in 1972, Faure mentioned the principles of lifelong learning and said, "Teaching should adapt itself to learning; contrary to the understanding of traditional education, the learner should not submit to the predetermined rules of teaching." With this statement, he revealed the importance of teaching-learning understandings. Studies on lifelong learning and self-efficacy (Garipagaoglu, 2013) and lifelong learning have focused on examining participants in terms of lifelong learning levels and various variables (Kaya, 2010; Tortop, 2010; Ersoy, 2009). While some studies have found a positive effect on lifelong learning trends and professional self-efficacy (Ayra \& Kosterelioglu, 2015), others have reached different findings in terms of gender (Kurt, Cevher, \& Arslan, 2019; Kangalgil \& Ozgul, 2018; Mulhim, 2018; Ozciftci, 2014).

\subsection{Present Study}

Many studies have been conducted on lifelong learning in the last decade (Eksi, Ozgenel, \& Metlilo, 2020; Kan \& Murat, 2020; Kurt, Cevher \& Arslan, 2019; Seifi, Habibi, \& Ayati, 2020; Mitkovska \& Hristovska, 2011; Woonsun, 2013). These studies on lifelong learning have mainly focused on participants' lifelong learning levels and their relationship with various variables. For example, while a positive effect was found on lifelong learning tendencies and professional selfefficacy (Ayra \& Kosterelioglu, 2015), some studies reached different findings on gender (Arcagok \& Sahin, 2014; Demiralay, 2008; Ozciftci, 2014). However, no study was found in the literatue on lifelong learning and teaching-learning approaches.

In the literature, teaching and learning conceptions and lifelong learning are seen as related variables. Teaching and learning conceptions have also been found to be associated with teacher self-efficacy (Yener \& Yilmaz, 2017; Sacici, 2013). Moreover, some research findings show that there is a positive relationship between lifelong learning and teacher self-efficacy (Akyol, 2016; Ayra \& Kosterelioglu, 2015; Garipagaoglu, 2013).

A review of the literature indicated that there were no studies examining the relationship between self-efficacy in organizing trips and lifelong learning tendencies in out-of-school learning environments. It is thought that learning to know and learning to do, which are the building blocks of lifelong learning, are related to professional development and that the individual's self-efficacy in teaching in out-of-school learning environments is related to professional development (Dinevski \& Dinevski, 2004; Kivrak, 2007; Saisana \& Cartwright, 
2007). It is considered that it is important to reveal the role of lifelong learning in the relationship between teacher candidates' teaching-learning conceptions and their self-efficacy in organizing out-of-school trips. For this reason, in this study, teaching-learning conceptions and self-efficacy in organizing out-of-school trips and the mediating role of lifelong learning were investigated. The hypothetical model of the research is given in Figure 1.

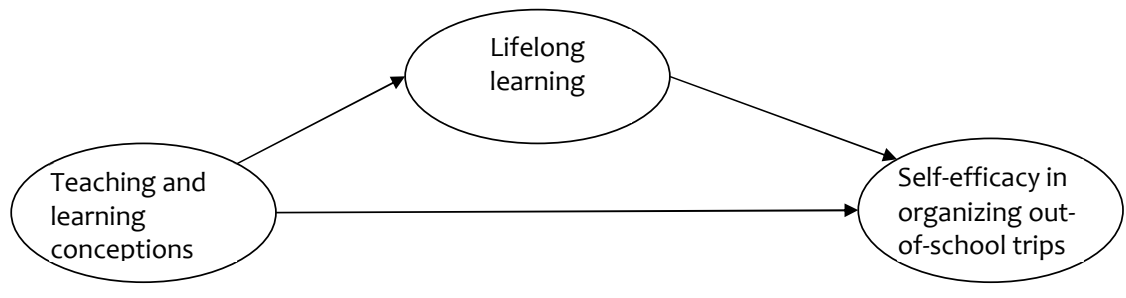

Figure 1. The hypothesed structural model

Based on the literature presented here, we put forward the following hypotheses. Each of these hypotheses represents a part of Fig. 1.

H1. Teaching and learning conceptions will be positively related to self-efficacy in organizing out-of-school trips.

$\mathrm{H} 2$. Teaching and learning conceptions will be positively related to lifelong learning tendencies. $\mathrm{H} 3$. Lifelong learning will be positively related to self-efficacy in organizing out-of-school trips. $\mathrm{H} 4$. The relationships between teaching and learning conceptions and self-efficacy in organizing out-of-school trips will be mediated by lifelong learning.

\section{Method}

\subsection{Research Model}

Structural Equation Modeling was used in this quantitative study. The study data were collected through a survey. Structural Equation Modeling is a statistical technique that tests the series of relationships between one or more independent variables, continuous or discontinuous, and one or more dependent variables. Independent and dependent variables can be either a factor or an observed variable (Tabachnick \& Fidell, 2007).

\subsection{Participants and Procedure}

The study sample consisted of 341 Turkish volunteer teacher candidates, including 257 females (75.4\%) and 84 males (24.6\%). Participants' ages ranged from 18 to 30 years (Mean $=23.26, \mathrm{SD}=$ 2.62). Data were collected with a cross-sectional study using the convenience sampling method in March 2020. A web-based survey was created to collect the data. Participants were first informed about the study and its importance, and then their informed consent was obtained. While collecting the data, participants were informed that no personal information would be collected, no individual evaluation would be done, and that the results of the research would only be used for scientific purposes. The web-based questionnaire was designed in such a way that participants could quit at any time. At the end of the survey, they were asked whether they would like to send their responses, and only those who volunteered could complete the survey. 


\subsection{Measures}

Teaching and Learning Conceptions Questionnaire: The teaching and learning conceptions of the participants in this study were assessed using the Teaching and Learning Conceptions Questionnaire (TLCQ; Chan \& Elliott, 2004). The scale consists of two sub-dimensions (constructivist and traditional). There are 12 items in the constructivist sub-dimension and 18 items in the traditional sub-dimension. Participants assess 30 items (e.g., "It is important that a teacher understands the feelings of the students") on a 5-point Likert-type scale ranging from 1 (strongly disagree) to 5 (strongly agree), with higher scores indicating higher levels of constructivist and traditional conceptions. In the present study, the Turkish version of the Teaching and Learning Conceptions Questionnaire (Aypay, 2011) was used. It was shown to have very good internal consistency reliability (constructivist sub-dimension, $\alpha=.88$; traditional sub-dimension, $\alpha=.83$ ), as well as acceptable construct validity (Aypay, 2011). The internal consistency coefficient in the present study was found as very good (Cronbach's a for the constructivist sub-dimension $=.81$; Cronbach's a for the traditional sub-dimension $=.86$ ).

Self-Efficacy Belief Scale for Planning and Organizing Educational Trips out of School: Participants' self-efficacy to organize out-of-school trips in this study was assessed using the Self-Efficacy Belief Scale for Planning and Organizing Educational Trips out of School (SEBS; Bozdogan, 2016). Of the 30 items on the scale, 13 are related to the before-trip stage, 12 to the during-trip stage, and 5 to the after-trip stage. Participants assess 30 items (e.g., "I know the necessary steps to organize an effective trip to out-of-school environments.", "I find it difficult to guide the students during the trip.", "I do not have difficulty giving information about the trip to students' families.") on a 5-point Likert-type scale ranging from 1 (never) to 5 (always), with higher scores indicating higher levels of self-efficacy of organizing trips to out-of-school environments. It was shown to have very good internal consistency reliability $(\alpha=.93)$, as well as very good construct validity (Bozdogan, 2016). The internal consistency coefficient in the present study was found as very good (Cronbach's $\alpha=.93$ ).

Lifelong Learning Scale: The lifelong learning tendencies of the participants in this study were assessed using the Lifelong Learning Scale (LLS; Wielkiewicz \& Meuwissen, 2014). Participants assess 16 items (e.g., "I enjoy intellectual challenges") on a 5-point Likert-type scale ranging from 1 (never) to 5 (always or daily), with higher scores indicating higher levels of lifelong learning tendencies. In the present study, the Turkish version of the Lifelong Learning Scale (Engin, Kor, \& Erbay, 2017) was used. It was shown to have very good internal consistency reliability $(\alpha=.93)$, as well as excellent construct validity $(\mathrm{CFI}=1.00 ; \mathrm{NFI}=1.00 ; \mathrm{AGFI}=.97 ; \mathrm{IFI}=$ .97; SRMR = .040; RMSEA = .061; Engin, Kor, \& Erbay, 2017). The internal consistency coefficient in the present study was found as very good (Cronbach's $\alpha=.83$ ).

\subsection{Data Analysis}

First, descriptive statistics, and then Pearson's correlation coefficients were calculated. Next, the mediation model of the study was tested. Maximum likelihood estimation was used in the structural equation model. Fit indices ( $\chi 2$ / df <5, CFI, TLI, GFI, IFI> .90, SRMR and RMSEA <.08; (Hu \& Bentler, 1999; Tabachnick \& Fidell, 2007)) were used to evaluate the research model. The item parceling method was used to reduce the number of observed variables and ensure normality (Alhija \& Wisenbaker, 2006). The parceling technique is used to reduce measurement error in one-dimensional scales with a large number of items (Little, Cunningham, Shahar, \& Widaman, 2002). Two plots were created for the Teaching and Learning Conceptions (constructivist conception) Questionnaire and three plots for the Lifelong Learning Scale. Besides, bootstrapping analysis was performed to determine whether lifelong learning had a 
mediating role in the relationship between teacher candidates' teaching-learning conceptions and self-efficacy in organizingout-of-school trips (Preacher \& Hayes, 2008). The data of the study were analyzed on IBM SPSS Statistics 21 (for descriptive statistics) and AMOS Graphics 23 (for hypothetical model) software packages.

\section{Results}

\subsection{Descriptive Statistics}

In this section, the mean scores of females, males, and all participants regarding teachinglearning conceptions, self-efficacy in organizing out-of-school trips, and lifelong learning tendencies are given. Descriptive statistics are presented in Table 1.

Table 1. Descriptive statistics

\begin{tabular}{|c|c|c|c|c|c|c|c|c|}
\hline & \multicolumn{2}{|c|}{ Female } & \multicolumn{2}{|c|}{ Male } & \multicolumn{2}{|c|}{ Total } & \multicolumn{2}{|c|}{$\begin{array}{l}\text { Mean } \\
\text { difference }\end{array}$} \\
\hline & $M$ & $S D$ & $M$ & SD & $M$ & $S D$ & $t$ & $\mathrm{p}$ \\
\hline Constructivist & 52.51 & 4.70 & 50.19 & 4.59 & 51.93 & 4.78 & 3.95 & .00 \\
\hline Traditional & 56.51 & 10.15 & 58.43 & 10.77 & 56.98 & 10.32 & -1.48 & .14 \\
\hline $\begin{array}{l}\text { Self-efficacy in } \\
\text { organizingout-of-school } \\
\text { trips }\end{array}$ & 124.01 & 16.08 & 117.64 & 20.37 & 122.44 & 17.42 & 2.94 & .00 \\
\hline Lifelong learning & 55.97 & 7.26 & $55 \cdot 32$ & 7.66 & 55.81 & $7 \cdot 36$ & .70 & .48 \\
\hline
\end{tabular}

Note. $M$, mean; SD, standard deviation ***

Mean scores for all variables in the study are given in Table 1. The mean score of the females from the constructivist conception ( $\bar{X}: 52.51$ ) was found significantly higher than that of the males ( $\bar{X}: 50.19)$. The mean score of females from the self-efficacy in organizing out-of-school trips $(\bar{X}: 124.01)$ was found significantly higher than that of males $(\bar{X}: 117.64)$. However, the mean scores of females from the traditional conception $(\bar{X}: 56.51)$ and lifelong learning tendencies $(\bar{X}: 55.97)$ were found close to those of males $(\bar{X}: 58.43$ and $\bar{X}: 55.81$, respectively).

\subsection{Correlation Analysis for Relationships between the Variables}

In the study, the relationships between teaching-learning conceptions, self-efficacy in organizing out-of-school trips, and lifelong learning were examined. Correlation values of the relationships between variables are presented in Table 2 .

Table 2. Correlations between the variables

\begin{tabular}{lllll}
\hline Variables & 1 & 2 & 3 & 4 \\
\hline 1. Constructivist conception & - & & & \\
2. Traditional conception & .08 & - & & \\
3. Self-efficacy in organizing out-of-school trips & $.36^{* *}$ & $-.12^{*}$ & - & $.35^{* *}$ \\
4. Lifelong learning & $.34^{* *}$ & .08 & - \\
\hline
\end{tabular}

Note. ${ }^{* *} p<.01,{ }^{*} p<.05$

Constructivist conception was found to be positively related to both self-efficacy in organizing out-of-school trips $(r=.36, p<.01)$ and lifelong learning $(r=.34, p<.01)$ (Table 2). Self-efficacy in organizing out-of-school trips was found to be positively related to lifelong learning $(r=.35$, 
$\mathrm{p}<$.01). There was no significant relationship between lifelong learning and traditional conception and constructivist conception. Therefore, traditional conception scores were not used in the hypothetical model of the study. In other words, of the teaching-learning conceptions, only constructivist conception scores were used.

\subsection{Measurement Model and CFA}

First, the measurement model was tested in the study. The measurement model included three latent variables and eight observed variables. As a result of the analysis, fit indices of the measurement model indicated a good fit $\left(\chi^{2}(17, \mathrm{~N}=341)=62.004, p<.001 ; \chi^{2} / \mathrm{df}=3.647 ; \mathrm{GFI}=.96\right.$; $\mathrm{CFI}=.97 ; \mathrm{NFI}=.96 ; \mathrm{TLI}=.95 ; \mathrm{SRMR}=.043 ; \mathrm{RMSEA}=.08)$. The loading, mean, standard deviation, composite reliability ( $C R$ ), average variance extracted (AVE), and Cronbach's a values of the measurement model of the study are presented in Table 3. Results showed that factor loadings ranged from .73 to .93 , CRs were greater than 0.70 , and that AVEs were greater than 0.50 . Reliability coefficients (Cronbach's a) were found above .72. All these results showed that the observed variables represented the latent variables.

Table 3. Correlations between the variables

\begin{tabular}{llllllll}
\hline Latent variables & Indicator & Loading & $M$ & SD & CR & AVE & $\alpha$ \\
\hline \multirow{2}{*}{ Constructivist conceptions } & CQPar1 & .75 & 25.73 & 2.62 & .78 & .71 & .81 \\
& CQPar2 & .93 & 26.21 & 2.57 & & & \\
Self-efficacy in organizing out- & BT & .90 & 48.30 & 7.78 & .86 & .74 & .93 \\
of-school trips & DT & .89 & 49.23 & 7.04 & & & \\
& AT & .79 & 20.81 & 3.50 & & & \\
Lifelong learning & LLPar1 & .83 & 17.87 & 2.81 & .72 & .58 & .83 \\
& LLPar2 & .74 & 18.69 & 3.01 & & & \\
& LLPar3 & .73 & 19.24 & 2.82 & & & \\
\hline
\end{tabular}

Note: CQPar, constructivist conception parcels; BT, before the trip; DT, during the trip; AT, after the trip; LLPar, lifelong learning parcels; M, mean; SD, standard deviation; CR, composite reliability; AVE, average variance extracted

\subsection{Structural Equation Model}

At this stage, the hypothetical model of the research was tested. In the model of the study, the mediating role of lifelong learning in the relationship between teaching-learning conceptions (constructivist conception) and self-efficacy in organizing out-of-school trips was tested. Results of the mediation model are presented in Figure 2. 


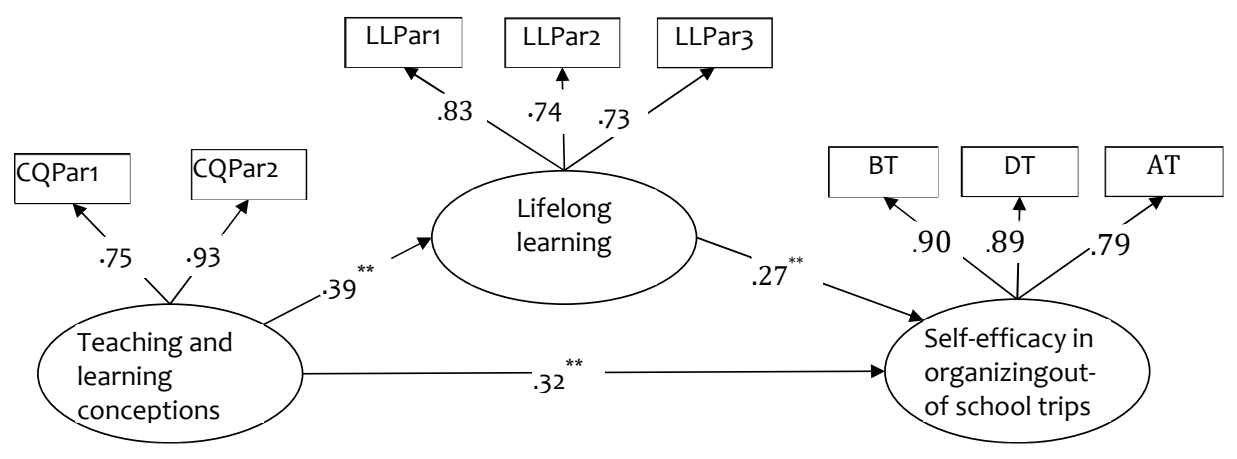

Figure 2. Mediation for teaching and learning conceptionsonself-efficacy in organizing out-of school trips via lifelong learning

As seen in Figure 2, all path coefficients are significant. In the model, teaching-learning conceptions (constructivist conception) positively predicted the self-efficacy in organizing outof-school trips $(\beta=.32, p<.01)$ (supporting $\mathrm{H} 1$ ) and lifelong learning $(\beta=.39, p<.01)$ (supporting $\mathrm{H} 2$ ). Lifelong learning positively predicted self-efficacy in organizing out-of-school trips ( $\beta=.27$, $\mathrm{p}<.01$ ) (supporting $\mathrm{H}_{3}$ ). In addition, the coefficient for teaching-learning conceptions predicting self-efficacy in organizing out-of-school trips through lifelong learning was found to be .11 (supporting $\mathrm{H} 4)$. The fit indices of the model $\left(\chi^{2}(16, \mathrm{~N}=341)=31.425, p<.001 ; \chi^{2} / \mathrm{df}=1.964 ; \mathrm{GFI}=.98\right.$; $\mathrm{CFI}=.99 ; \mathrm{NFI}=.98 ; \mathrm{TLI}=.98 ;$ SRMR $=.036 ; \mathrm{RMSEA}=.05)$ were all at a good level, and the structural equation model was confirmed.

Bootstrapping analysis was used to determine whether direct and indirect effects were significant in the study. In bootstrapping analysis, a resampling size of 10000 and a $95 \%$ confidence interval were used. The results of the Bootstrapping analysis are presented in Table 4 .

Table 4. The results of the bootstrapping analysis

\begin{tabular}{llcc}
\hline Model paths & Coefficient & Lower & Upper \\
\hline Direct effect & & & \\
Teaching and learning conceptions $\rightarrow$ Self-efficacy in organizing & .32 & .18 & .45 \\
out-of-school trips & & .39 & .52 \\
Teaching and learning conceptions $\rightarrow$ Lifelong learning & .25 & .39 \\
$\begin{array}{l}\text { Lifelong learning } \rightarrow \text { Self-efficacy in organizingout-of-school trips } \\
\text { Indirect effect }\end{array}$ & .27 & .05 & .17 \\
$\begin{array}{l}\text { Teaching and learning conceptions } \rightarrow \text { Lifelong learning } \rightarrow \text { Self- } \\
\text { efficacy in organizing out-of-school trips }\end{array}$ & .11 & & \\
\end{tabular}

According to the results of the bootstrapping analysis in Table 4, all direct and indirect effects were significant. There was no zero in the lower and upper coefficient range of the direct and indirect effects, and this result showed that all effects were significant.

\section{Discussion}

We investigated the mediating role of lifelong learning in the relationship between teachinglearning conceptions and self-efficacy in organizing out-of-school trips in this study. All of the 
fit indices of the structural equation model of the study were accepted (Hu \& Bentler, 1999). As a result, it was observed that the structural equation model of the study, which examined the mediating role of lifelong learning in the relationship between teacher candidates' teachinglearning conceptions and self-efficacy for out-of-school trips, was confirmed.

Discussion of each result obtained in the study is considered important in terms of understanding the relationships between variables. There was no significant relationship between the traditional conception, which is one of the teaching-learning approaches, and other variables of the study. For this reason, the mean traditional conception scores were not used in the hypothetical model of the study. In other words, only the mean constructivist conception scores, one of the teaching-learning conceptions, were employed.

First, we examined whether gender had an effect on the variables of the study. The mean scores of females from the teaching-learning conceptions (constructivist approach) were found to be significantly higher than those of males. The results of some studies in the literature are similar to ours (Erdogan, 2014; Evin Gencel, 2013), but there are some different results, as well (Arcagok \& Sahin, 2014; Tunca, Sahin, \& Aydin, 2015). According to research findings, female teacher candidates have a more constructivist conception than male teacher candidates. This difference in the literature is thought to stem from the fact that teacher candidates receive education in different disciplines, live in different regions, and grow up in different cultures. The mean scores of females from the self-efficacy in organizing out of school trips were found to be significantly higher than those of males. While there are few studies in the literature showing that teachers' self-efficacy differs according to gender, parallel to the findings obtained from this study, (Aypay, 2010; Capri \& Celikkaleli, 2008; Ekici, 2005), some studies indicate that self-efficacy beliefs do not differ by gender (Akyildiz, 2016; Ekici, 2008; Endler, Speer, Johnson, \& Flett, 2001; Inel Ekici, 2014; Ozpulat, 2016; Uysal \& Kosemen, 2013; Yalmanci \& Aydin, 2014). For example, Sontay and Karamustafaoglu found that science teachers' self-efficacy for organizing out-ofschool trips did not differ by gender. According to the findings of the present study, it can be concluded that male and female teacher candidates have different self-efficacy beliefs for organizing out-of-school trips and that female teacher candidates believe in themselves more in this respect. Oner (2015) stated that female teachers were more willing to organize out-ofschool trips than male teachers. This finding may explain why female teacher candidates' selfefficacy scores for organizing out-of-school trips are higher than those of male teacher candidates.

The mean lifelong learning scores of female teacher candidates were close to the mean scores of male teacher candidates. Some studies in the literature have findings similar to those of the present study (Arcagok \& Sahin, 2014; Aydin, 2018; Dogan \& Kavtelek, 2015; Kurt, Cevher \& Arslan, 2019; Oral \&Yazar, 2013; Tunca, Sahin, \& Aydin, 2015; Yaman \& Yazar, 2015). There are also some studies that show differences in terms of gender (Demiralay, 2008; Evin Gencel, 2013; Erdogan, 2014; Kangalgil \& Ozgul, 2018; Yavuz Konokman \& Yanpar Yelken, 2014) and those in favor of males (Diker, Coskun, 2009; Mulhim, 2018; Ozciftci, 2014). According to the findings of the present study, the mean lifelong learning scores of female teacher candidates were close to those of male teacher candidates. In the study conducted by Johnstone (1965) in the USA, females and males were found to participate equally in activities of adult education. It can be concluded that the gender variable is not effective in lifelong learning tendencies, females take on an active role in academic and business life today, and that males gain knowledge and skills because they need to further develop themselves in areas other than traditional fields. The gender variable may have caused no differences in lifelong learning tendencies for these reasons. 
In the model of the study, the teaching-learning conceptions of the teacher candidates (constructivist conception) positively predicted self-efficacy in organizing out-of-school trips (H1). No research findings addressing the relationship between these two variables have been found in the literature. However, there are some studies that have shown the relationship between teaching-learning conceptions and self-efficacy (Yener \& Yilmaz, 2017; Sacici, 2013). These studies reported that there was a significant positive relationship between perceived self-efficacy and teaching-learning conceptions. In general, the research results mentioned here support the results of the current study. When the results of the present study are evaluated, it can be thought that as the teacher candidates' beliefs in the constructivist approach increase, their self-efficacy in organizing trips to out-of-school learning environments increases, as well. Self-efficacy belief can be defined as individuals' thoughts about their own capacity in the process of performing a certain job, and their confidence in their ability and skills to perform it (Bandura, 1977). It is thought that the self-efficacy of teacher candidates who have a constructivist conception in organizing trips to out-of-school environments increases because according to the constructivist approach, individuals who learn by doing-experiencing will believe in themselves more to do a job, and thus their self-efficacy beliefs will increase.

Teacher candidates' teaching-learning conceptions (constructivist conception) positively predicted their lifelong learning $\left(\mathrm{H}_{2}\right)$. No relationship was found between these two variables in the literature. According to the results of the present study, it can be thought that as teacher candidates' beliefs in the constructivist conception increase, their lifelong learning increases, as well. In the constructivist conception, a student-centered approach dominates, the student is active, collaborative learning takes place, learners make sense of their knowledge and experiences, and they actively participate in the construction and development of knowledge (Cheng, Chan, Tang, \& Cheng, 2009). Lifelong learning, on the other hand, has a structure that involves more than one teaching style and provides individuals with education options ranging from appropriate personal development education to formal education or from unplanned education in daily life to non-formal education. An individual who is educated with a constructivist approach is prepared for life through learning by doing and experiencing. It is thought that lifelong learning situations will develop in this way. The individual is active in both constructivist education and lifelong learning. For this reason, it can be concluded that teacher candidates who have a constructivist conception will maintain and increase lifelong learning.

The life-long learning of the teacher candidates positively predicted their self-efficacy in organizing out-of-school trips $\left(\mathrm{H}_{3}\right)$. Some studies have shown that there is a positive relationship between lifelong learning and self-efficacy (Garipagaoglu, 2013), academic selfefficacy (Kozikoglu \& Onur, 2019), and teacher self-efficacy (Akyol, 2016; Ayra \& Kosterelioglu, 2015). According to Delors (1996), lifelong learning is a long-term learning process where individuals see the available possibilities and can evaluate them appropriately, they can find solutions to the problems they encounter by using their problem-solving skills, and they can live peacefully in society. In lifelong learning, individuals see it as their responsibility/preference to make appropriate choices among the educational services or learning areas offered. It is thought that individuals with these skills will also have high self-efficacy. Therefore, it can be inferred that individuals with high lifelong learning tendencies also have high self-efficacy.

Finally, the mediating role of lifelong learning in the prediction of teacher candidates' selfefficacy in organizing out-of-school trips through their teaching-learning conceptions was confirmed $\left(\mathrm{H}_{4}\right)$. There are no studies in the literature that test the variables aforementioned through a model. An innovative teacher is a person who has lifelong tendencies and improved self-efficacy, has adopted a constructivist approach (learner-centered), and is collaborative and creative (Chen, 2002; Karwowski, Jacek, Lebuda, \& Wisniewska, 2007; OECD, 2009). It is 
considered that this study revealed the relationship between teacher candidates' lifelong learning and their teaching-learning conceptions and self-efficacy in organizing out-of-school trips and indicated that teacher candidates' lifelong learning tendencies strengthened the relationship between their teaching-learning conceptions and self-efficacy in organizing out-ofschool trips.

\section{Limitation and Suggestions}

In this study, the mediating role of lifelong learning between teaching-learning conceptions and self-efficacy in organizing out-of-school trips was investigated. First, the personal characteristics of teacher candidates who participated in the study and the sample size do not represent all teacher candidates in Turkey. In future studies, the use of a larger sample and the inclusion of teacher candidates from various regions of Turkey can increase the generalizability of the study. Secondly, this study used self-report scales. We also recommend using qualitative data collection methods. Besides, the data were collected under the effect of the COVID-19 pandemic. Future studies can be carried out in the absence of pandemic fear. Thirdly, the fact that the participants were reached during the pandemic process prevented the homogeneous distribution of some variables such as gender because the data collection process was carried out online and voluntarily. We spent some effort to make up for this drawback, but the problem could not be prevented. Finally, this study can be conducted with teacher candidates from other countries, too, to make intercultural comparisons.

\section{Conclusion}

In conclusion, it was determined that lifelong learning tendencies had a mediating role in the relationship between teaching-learning conceptions and self-efficacy in organizing out-ofschool trips. The study used the structural equation model. As teacher candidates' beliefs in the constructivist approach increased, their self-efficacy in organizing trips to out-of-school learning environments increased, as well. It is thought that the self-efficacy of teacher candidates who have a constructivist conception in organizing trips to out-of-school environments increases because according to the constructivist approach, individuals who learn by doing-experiencing will believe in themselves more to perform a job, and thus their self-efficacy beliefs will increase. Besides, as teacher candidates' beliefs in constructivist conception increase, their lifelong learning tendencies also increase. An individual who is educated based on a constructivist approach is prepared for life through learning by doing and experiencing. Thus, it is thought that this will develop their lifelong learning capacity. In the study, the life-long learning of the teacher candidates positively predicted their self-efficacy in organizing out-of-school trips. In lifelong learning, it is individuals' own responsibility/ preference to make appropriate choices among educational services or learning areas offered. It is thought that individuals with these tendencies will also have high self-efficacy. Therefore, it can be concluded that individuals with high lifelong learning tendencies also have high selfefficacy.

Finally, the mediating role of lifelong learning in the prediction of teacher candidates' selfefficacy in organizing out-of-school trips through their teaching-learning conceptions was confirmed. This study revealed the relationship between the lifelong learning of teacher candidates, who will start their profession for the first time, and their teaching-learning conceptions and self-efficacy in organizing out-of-school trips. In conclusion, it can be said that teacher candidates' lifelong learning tendencies strengthen the relationship between their teaching-learning conceptions and self-efficacy in organizing out-of-school trips. 


\section{References:}

Abdelraheem A.Y. (2004). University faculty members' context beliefs about technology utilization in teaching. The Turkish Online Journal of Educational Technology, 3(4), 76-84.

Akyildiz, S. (2014). Investigating the relationship between high school teachers' epistemological beliefs and their teaching-learning approaches [Unpublished Doctoral Thesis]. Firat University.

Akyildiz, S. (2016). Investigating novice teachers' teaching-learning approaches on the basis of adoption of curriculum and application variables. Journal of Bayburt Education Faculty, $11,1$.

Akyol, B. (2016). Teacher self-efficacy perceptions, learning oriented motivation, lifelong learning tendencies of candidate teachers: a modeling study. Eurasian Journal of Educational Research, 65, 19-34.

Alhija, F., \& Wisenbaker, J. (2006). A monte carlo study investigating the impact of item parceling strategies on parameter estimates and their standard errors in CFA. Structural Equation Modeling, 13(2), 204-228.

Anderson, D., Kisiel, J. \& Storksdieck, M. (2006). Understanding teachers' perspectives on fiels trips: discovering common ground in three countries. Curator, 49(3), 364- 386.

Arcagok, S. \& Sahin, C. (2014). Examination of the teachers' lifelong learning competences levels in terms of some variables. Adiyaman University Journal of Social Sciences Institute, 16, 394-417.

Aston, P.T. (1984). Teacher efficacy: A motivational paradigm for effective teacher education. Journal of Teacher Education, 35(5), 28-32.

Aydin M. (2010). Examining changes in mathematics teachers? beliefs towards mathematics education [Unpublished Doctoral Thesis]. Karadeniz Teknik University.

Aydin, B. (2018). The relationship between the lifelong learning tendency and the career development desire of primary school teacher candidates [Unpublished Master's Thesis]. Abant Izzet Baysal University.

Ayra, M., \& Kosterelioglu, I. (2015). The relationship between teachers' lifelong learning tendencies and their perceptions of professional self-efficacy. Education Sciences, 10(1), 17-28.

Aypay, A. (2010). The adaptation study of general self-efficacy (GSE) scale to turkish. Inonu University Journal of The Faculty of Education, 11(2), 113-131.

Aypay A. (2011). The adaptation of the teaching-learning conceptions questionnaire and its relationships with epistemological beliefs. Educational Sciences: Theory \& Practice, 11(1), 21-29.

Bagci, S. E. (2007). Lifelong education policies in european union countries: a comparative study on germany, denmark and turkey [Unpublished Master's Thesis], Ankara University.

Bandura, A. (1977). Toward a unifying theory of behavioral change. Psychological Review, 84(2), 191-215. doi:10.1037/0033-295X.84.2.191

Bas G., \& Beyhan O. (2013). Correlation between pre-service teachers' teaching-learning conceptions and their student control ideologies. H. U. Journal of Education, Special Issue, 1,14-26.

Bikmaz, F. (2017). Investigating the teaching and learning conceptions and scientific epistemological beliefs of pre-service teachers': a longitudinal study. Education and Science, 42(189), 183-196.

Bozdogan, A. (2016). Development of self-efficacy belief scale for planning and organizing educational trips to out of school settings. Journal of Theoretical Educational Science, 9(1), 111-129.

Bozdogan, A. E. (2007). Role and importance of science and technology in education [Unpublished Doctoral Thesis]. Gazi University. 
Bozdogan, A.E. (2012). The practice of prospective science teachers regarding the planning of education based trips: evaluation of six different field trips. Educational Science; Theory and Practice, 12(2), 1049-1072.

Brooks, J. G., \& Brooks, M. G. (1999). The case for constructivist classrooms. Alexandria Press.

Brownlee, J., Purdie, N., \& Boulton-Lewis, G. (2001). Changing epistemological beliefs in preservice teacher education students. Teaching in Higher Education, 6, 247- 268.

Burns, G.E. (2001). Toward a redefinition of formal and informal learning: education and the aboriginal people. NALL Working Paper.

Chan K. W., \& Elliott R. G. (2004). Relational analysis of personel epistemology and conceptions about teaching and learning. Teaching and Teacher Education, 20(8), 817-831.

Chan, K. W. (2003). Hong Kong teacher education students' epistemological beliefs and approaches to learning. Research in Education, 69, 36-50.

Chapman, J., Toomey, R., Gaff, J., McGlip, J., Walsh, M., Warren, E., \&Williams, I. (2003) Lifelong learning and teacher education. Canberra: Australian Government Department of Education, Science and Training. www.dest.gov.au/highered/eippubs.htm

Chen, X. Y. (2002). On the development of innovative teacher and innovative quality. Aspect South-East Asia, 10, 55-59.

Cheng, M. M. H., Chan, K. W., Tang, S. Y. F., \& Cheng, A. Y. N. (2009). Pre-service teacher education student' epistemological beliefs and their conceptions of teaching. Teaching and Teacher Education, 25, 319-322.

COM (2000). Commission Staff Working Paper: A Memorandum on Lifelong Learning. Commission of the European Communities. Brussels.

Cox-Petersen, A.M., Marsh, D.D., Kisiel, J., \& Melber, L.M. (2003). Investigation of guided school tours, student learning, and science reform recommendations at a museum of natural history. Journal of Research in Science Teaching, 40, 200-218.

Capri, B., \& Celikkaleli, O. (2008). Investigation of preservice teachers' attitudes towards teaching and professional self-efficacy beliefs according to their gender, programs, and faculties. Inonu University Journal of Education Faculty, 9(15), 33-53.

Delors, J. (1996). Education: The necessary utopia. Learning: The treasure within, (13-35). UNESCO publition.

Demiralay, R. (2008). An evaluation of student teachers' information literacy self-efficacy in point of usage of information and communication technologies [Unpublished Master Thesis]. Gazi University.

Demirel, M., \& Yagci, E. (2012). Lifelong learning tendencies of primary school teacher candidates. H. U. Journal of Education, 1, 100-111.

DeWitt, J., \& Osborne, J. (2007). Supporting teachers on science focused school trips: towards an integrated framework of theory and practice. International Journal of Science Education, 29(6), 685-710.

Diker Coskun, Y. (2009). Investigation of life long learning tendency of undergraduate students? In terms of some variables [Unpublished Doctoral Thesis], Hacettepe University.

Dinevski, D. \& Dinevski, I. V. (2004). The concepts of university lifelong learning provision in Europe. Transition Studies Review, 11(3), 227-235.

Dogan, S., \& Kavtelek, C. (2015). Perceptions of lifelong learning institution administrators about lifelong learning. Abant Izzet Baysal University Journal of Education Faculty, 15(1), 82-104.

Ekici, G. (2005). Egitim fakultesi ogrencilerinin ogretmenlik oz-yeterlik inanclarini etkileyen faktorler. XIV. Ulusal Egitim Bilimleri Kongresi, Pamukkale Universitesi Egitim Fakultesi, Denizli.

Ekici, G. (2008). The effects of the classroom management lesson on preservice teachers' teacher sense of self-efficacy H. U. Journal of Education, 35, 98-110. 
Eksi, H., Ozgenel, M., \& Metlilo, E. (2020). The effect of motivation of success of university students on personal-professional competence: Mediation role of lifelong learning tendency. International Journal of Evaluation and Research in Education, 9(3), 583-593.

Endler, N. S., Speer, R. L., Johnson, R. M., \& Flett, G. L. (2001). General self-efficacy and control in relation to anxiety and cognitive performance. Social Spring, 20 (1), 36-52.

Engin, M., Kor, H., \& Erbay, H. (2017). Turkish adaptation study of lifelong learning scale. Kastamonu Education Journal, 25(4), 1561-1572.

Erdogan, D.G. (2014). Factors effecting lifelong learning inclinations of prospective teachers [Unpublished Doctoral Thesis]. Abant Izzet Baysal University.

Ersoy, A., (2009). Lifelong learning and public libraries in turkey. [Unpublished Master Thesis], Hacettepe University.

Evin Gencel, I. (2013). Prospective teachers' perceptions towards lifelong learning competencies. Education and Science, 38(170), 237-252.

Faure, E., Herrera, F., Kaddoura, A. R., Lopes, H., Petrovsky, A. V., Rahnema, M. \& Champion Ward, F. (1972). Learning to be. The world of education today and tomorrow, (Paris, UNESCO). http://unesdoc.unesco.org/images/0000/00001 8/001801E.pdf)

Fenwick, T. (2003) Reclaiming and re-embodying experiential learning through complexity science. Studies in the Education of Adults, 35, 123-141.

Garipagaoglu, B. C. (2013). The effect of self-efficacy on the lifelong learning tendencies of computer education and instructional technologies students: a case study. Journal of Human Sciences, 10(1), 224-236.

Griffin, J. (2004). Research on students and museums: looking more closly at the students in school groups. Science Education, 88(1), 59- 70.

Griffin, J., \& Symington, D. (1997). Moving from task-oriented to learning-oriented strategies on school excursions to museums. Science Education, 81(6), 763-779.

Gulec, I., Celik, S., \& Demirhan, B. (2012). What is lifelong learning? an evaluation on definition and scope. Sakarya University Journal of Education, 2(3), 34-48.

Henson R. K.(2001). Teacher self-efficacy: substantive implications and measurement dilemmas. Teacher Efficacy Research. https://files.eric.ed.gov/fulltext/ED452208.pdf

Holmes, A. (2002). Lifelong learning. Capstone Publishing.

Hu, L. T., \& Bentler, P. M. (1999). Cutoff criteria for fit indexes in covariance structure analysis: conventional criteria versus new alternatives. Structural Equation Modeling: A Multidisciplinary Journal, 6(1), 1-55. doi:10.1080/10705519909540118

Inel Ekici, D. (2014). Pre-service science teachers' views on creativity in science teaching and selfefficacy perceptions about implementing the creative thinking activities. Dicle University Journal of Ziya Gokalp Education Faculty, 23, 142-172.

Kan, A.U., \& Murat, A. (2020). Examining the self-efficacy of teacher candidates' lifelong learning key competences and educational technology standards. Education Informal Technolgy, 25, 707-724. https://doi.org/10.1007/s10639-019-10072-8

Kangalgil, M. \& Ozgul, F. (2018). Investigation of physical education and sports training students in lifelong learning trends. Journal of Global Sport and Education Research, 1(1), 64-72.

Karademir, E. (2018). Guncel yaklasım ve yontemlerle etkinlikli fen ogretimi. O. Karamustafaoglu, O. Tezel, U. Sari (Eds.), Okul disi ogrenme ortamlari into (s. 85-104). Ankara: Pegem Akademi Press.

Karhan, I. (2007). The investigation of epistemological beliefs of primary school teachers according to some demographic variables and their information technology use [Unpublished Doctoral Thesis]. Yildiz Teknik University.

Karwowski, M., Gralewski, J., Lebuda, I., \& Wisniewska. E. (2007). Creative teaching of creativity teachers: Polish perspective. Thinking Skills and Creativity, 2(1), 57-61.

Kaya, H.E. (2010). European Union lifelong learning and adult education policies. [Unpublished Doctoral Thesis] Ankara University. 
Khader, F. R. (2012). Teachers' pedagogical beliefs and actual classroom practices in social studies. American International Journal of Contemporary Research, 2(1), 73-92.

Kisiel, J. F. (2005). Understanding elementary teacher motivations for science fieldtrips. Science Education, 89(6), 936-955.

Kozikoglu, I. \& Onur, Z. (2019). Predictors of lifelong learning: information literacy and academic self-efficacy. Cypriot Journal of Educational Science, 14(4), 492-506. https://doi.org/10.18844/cjes.v11i4.3460

Kozulin, A. (2003). Psychological tools and mediated learning. Cambridge University Press.

Kurt, E., Cevher, T., \& Arslan, N. (2019). Pre-service turkish teachers' tendencies towards lifelong learning. Trakya Journal of Education, 9(1), 152-160. https://doi.org/10.24315/Tred.473391

Kivrak, E. (2007). Avrupa birligi ve turkiye'de yasamboyu ogrenme politikaları ve istihdam iliskisinin degerlendirilmesi [Unpublished Master's Thesis]. Ankara University.

Little, T. D., Cunningham, W. A., Shahar, G., \& Widaman, K. F. (2002). To parcel or not to parcel: Exploring the question, weighing the merits. Structural equation modeling, 9(2), 151-173.

Lucas K.B. (2000). One teacher's agenda for a class visit to an interactive science center. Science Education, 84(4), 524-544.

Mitkovska, S., \& Hristovska, D. (2011). Contemporary teacher and core competences for lifelong learning. Procedia-Social and Behavioral Sciences, 28, 573-578.

Mulhim, M.A. (2018). Examination of individual innovation levels and lifelong learning trends of students with physical education and sports high school students: Bartın University example [Unpublished Master's Thesis]. Bartın University.

OECD (Organisation for Economic Co-operation and Development), (2009). Creating effective teaching and learning environments: first results from TALIS. Teaching and learning international survey. Paris. https://www.oecd.org/education/school/43023606.pdf

Oral, B., \& Yazar, T. (2013). International perspectives on new aspectes of learning in teacher education. IPALTE 2013. Dicle University. Diyarbakır.

Orion, N., \& Hofstein, A. (1994). Factors that influence learning during a scientific field trip in a natural environment. Journal of Research in Science Teaching, 31(10), 1097-1119.

Oner, G. (2015). Examination of the opinions of social studies teachers about outdoor history teaching. Turkish History Education Journal, 4(1), 89-121.

Oner, G., \& Ozturk, M. (2019). Science Centres as Outdoor Teaching Environments: Experience of Prospective Social Studies Teachers. Eskişehir Osmangazi University Journal of Social Sciences, 20 (Special Issue). https://doi.org/10.17494/ogusbd.

Ozciftci, M. (2014). The relationship between primary school teachers' lifelong learning trends and self-efficiencies about the educational technology standards [Unpublished Master Thesis]. Amasya University.

Ozden Y. (2014). Ogrenme ve ogretme. Pegem Akademi Press.

Ozpulat, F. (2016). The relationship between self-efficacy level and gender perception of university students: Beysehir example. International Journal of Human Sciences, 13(1), $1222-1232$.

Plourde, L.A. (2001). The genesis of science teaching in the elementary school: the influence of student teaching. http://www.ed.psu.edu/Cl/Journals/2001aets/su1_08_plourde.rtf.

Preacher, K. J., \& Hayes, A. F. (2008). Assessing mediation in communication research. The Sage sourcebook of advanced data analysis methods for communication research, 13-54.

Rapp, W. (2005). Inquiry-based environments for the inclusion of students with exceptional learning needs. Remedial and Special Education, 26(5), 297-310.

Richardson V. (1996). The role of attitudes and beliefs in learning to teach. Handbook of Research on Teacher Education, 2, 102-119.

Roulstone, K. (2010). There is no end to learning': lifelong education and joyful learner. International Journal of Music Education, 28(4), 341-352. 
Sacici, S. (2013). The interrelation between pre-service science teachers' conceptions of teaching and learning, learning approaches and self-efficacy beliefs [Unpublished Master's Thesis]. Middle East Technıcal University.

Saisana, M. \& Cartwright, F. (2007). Measuring lifelong learning and its impact on happiness: the canadian paradigm. International Conference on Policies for Happiness, Siena.

Seifi L., Habibi M., \& Ayati M. The effect of information literacy instruction on lifelong learning readiness. IFLA Journal. 46(3), 259-270. https://doi.org/10.1177/0340035220931879

Skinner, B. F. (1953). Science and human behavior. Free Press.

Sontay, G., \& Karamustafaoglu, O. (2017). Investigation of science teachers' self-efficacy beliefs related to trip arrangement. H. U. Journal of Education, 32(4), 863-879. https://doi.org/10.16986/HUJE.2017027586

Soran, H., Akkoyunlu, B., \& Kavak, Y (2006). Life-long learning skills and training faculty members: A project at hacettepe university. H. U. Journal of Education, 30, 201- 210.

Stipek, D., J., Givvin, K., B., Salmon, J. M., \& Macgyvers, V.,L., (2001). Teachers' beliefs and practices related to mathematics instruction, Teaching and Teacher Education, 17, 213226.

Tabachnick, B. G., \& Fidell, L. S. (2007). Using multivariate statistics. Pearson.

Teo T., Chai S.C., Hung D., \& Lee C.B. (2008). Beliefs about teaching and uses of technology among preservice teachers. Asia-Pacific Journal of Teacher Education 36(2), 163-174.

Thomas, G. (2010). Facilitator, teacher, or leader? managing conflicting roles in outdoor education. Journal of Experiential Education, 32(3), 239-254.

Tortop, O. (2010). European union key competencies for lifelong learning: turkey case. [Unpublished Master's Thesis]. Gazi University.

Tschannen, M., \& Woolfolk, H. (2001). Teacher efficacy: capturing an elusive construct. Teaching and Teacher Education, 17, 783-805.

Tunca, N., Sahin, S. A., \& Aydin,O. (2015). Life-long learning tendencies of pre-service teachers. Mersin University Journal of the Faculty of Education, 11(2), 432-446.

Uysal, I., \& Kosemen, S. (2013). Analysis of the pre-service teachers' general self-esteem beliefs. Journal of Research in Education and Teaching, 2(2), 217-226.

Wielkiewicz, R. M., \& Meuwissen, A. S. (2014). A lifelong learning scale for research and evaluation of teaching and curricular effectiveness. Teaching of Psychology, 41(3), 220227.

Woonsun, K. (2013). Korean pre-service teachers' service learning and lifelong learning competency. Procedia-Social and Behavioral Sciences. 5th World Conference on Educational Sciences (WCES 2013) https://doi.org/76 10.1016/j.sbspro.2014.01.792

Yalmanci, S. G., \& Aydin, S. (2014). Investigation of prospective scienve teachers' academic selfefficiacy perceptions. Kafkas Journal of Educational Research, 1(1), 60-66.

Yaman, F., \& Yazar, T. (2015). Investigating of life long learning tendency of teachers (the example of diyarbakir). K. U. Kastamonu Journal of Education, 23(4), 1553- 1566.

Yavuz Konokman, G., \& Yanpar Yelken, T. (2014). The perceptions of academicians in education faculties on their lifelong learning competencies. H. U. Journal of Education, 29(2), 267281.

Yener, D., \& Yilmaz M. (2017). Teacher candidates' conceptions about teaching and learning and their science teaching self efficacy beliefs. Abant Izzet Baysal University Journal of Education Faculty, 17(2), 1016-1038.

Yildirim, Z. (2015). Classroom teachers' views and efficacy perceptions on lifelong learning [Unpublished Master's Thesis]. Canakkale Onsekiz Mart University.

Yurdakul B. (2015). Yapilandirmacilik. Into Demirel O, (Ed.). Egitimde Yeni Yonelimler. Pegem Akademi Press. 


\section{Biographical notes:}

Dr. Büşra Bakioglu is an Assistant Professor in the Department of Mathematics and Science Education at Karamanoglu Mehmetbey University, Turkey. Her current research interests are science education, out-of school environment and teacher education.

https://orcid.org/0000-0001-7997-1018 